\title{
ORGANOPHOSPHATE EXPOSURE, ASSOCIATED RISK FACTORS AND EXPOSURE RISK ASSESSMENT AMONG VEGETABLE FARMERS IN SABAH, MALAYSIA
}

\author{
Bitinsun Botinggo ${ }^{1}$, Khamisah Awang Lukman ${ }^{2,3}$, Sahipudin Saupin ${ }^{3}$, Chee Fong Tyng ${ }^{4}$ and Mohammad \\ Saffree Jeffree ${ }^{3}$. \\ ${ }^{1}$ Kota Kinabalu Area Health Office, Sabah Health Department, Kota Kinabalu, Sabah, Malaysia. \\ ${ }^{2}$ Center for Occupational Safety and Health, Universiti Malaysia Sabah, Kota Kinabalu, Sabah, Malaysia. \\ ${ }^{3}$ Public Health Medicine Department, Faculty of Medicine and Health Sciences, Universiti Malaysia Sabah, \\ Kota Kinabalu, Sabah, Malaysia. \\ ${ }^{4}$ Faculty of Sustainable Agriculture, Universiti Malaysia Sabah, Sandakan, Sabah, Malaysia.
}

Corresponding author: Khamisah Awang Lukman

Email: khamisah@ums.edu.my

\begin{abstract}
Uncontrolled use of pesticides in agriculture may result in increased health risks. Organophosphate (OP) pesticides are widely used among vegetable farmers to control pests and increase productivity. The aim is to determine the organophosphate exposure, associated risk factors, and exposure risk assessment among vegetable farmers in Sabah. A cross-sectional study design in Kundasang, Sabah, Malaysia. We took a blood sample from participants for blood cholinesterase concentration measurements of pesticide exposure using the rapid test kit model Lovibond AF267. A validated questionnaire was used to collect the associated risk factors of vegetable farmers. The Hazard Identification, Risk Assessment, Risk Control (HIRARC) guidelines were used for exposure risk assessment of OP exposure. The response rate was $91.1 \%$. About $23.3 \%$ (38 out of 163) have abnormal blood cholinesterase. The significant associated risk factors were age $[a O R=1.07,95 \% \mathrm{Cl}(1.02,1.13)]$, Body Mass Index $[a O R=8.60,95 \% \mathrm{Cl}(2.80,26.51)]$, frequency of exposure a month $[a O R=5.99,95 \% \mathrm{Cl}(1.29,27.76)]$, had not attended pesticide safety training $[a O R=9.08,95 \% \mathrm{Cl}(2.97,27.74)]$, no designated pesticide storage $[a O R=6.92,95 \% \mathrm{Cl}(1.70,28.25)]$ and low practices scores on pesticide handling [aOR=6.01, 95\% Cl $(1.97,18.36)]$. The exposure risk assessment level for vegetable farmers was at low-medium risk. Organophosphate exposure among the vegetable farmers in Kundasang was higher than in other settings. The risk factors associated with organophosphate exposure were related to inadequate compliance to the standard occupational safety and health practices in agriculture. Exposure assessment revealed the opportunity for improvement by implementing the recommended control measures. Vegetable farmers need continuous support from relevant authorities. Further research is required to understand better the health risks among vegetable smallholder farmers in Sabah.
\end{abstract}

Keywords: Organophosphate pesticide exposure, associated risk factors, exposure risk assessment, vegetable farmers

\section{INTRODUCTION}

The agricultural industry remains an important sector in Malaysia, accounting for $7.3 \%$ of gross domestic product (GDP) in $2018^{1}$. Pesticides are agricultural technologies that enable farmers to control pests and weeds and constitute an important input when producing crops $^{2}$. Food crops refer to vegetables, fruit, root crops, and grain crops associated with smallholdings managed by individual farmers. The average farm size in Malaysia is $1.45 \mathrm{ha}^{3}$. Due to their toxicity and widespread use in agricultural settings, pesticides pose a severe threat to rural populations, particularly children and farmers in low-income countries $^{4}$. The unsafe use of pesticides in agriculture represents a significant hazard to the environment and human health ${ }^{5}$. Many studies on pesticide residues have produced evidence of increased incidence of acute pesticide poisoning and long-term effects such as cancer ${ }^{6}$. However, poisoning cases due to pesticide exposure in agriculture activities are not well documented in Malaysia.

A survey showed that poisoning had occurred in $14.5 \%$ of the 4,531 farmers growing vegetables, flowers, and fruit in the Cameron Highlands. At government health facilities in Malaysia between 1999 and 2001, 21714 hospital admissions and 779 deaths related to poisoning were recorded. The most significant number of fatalities was said to be due to pesticide poisoning ${ }^{7}$. Most of the communities in Kundasang are small-scale vegetable farmers. They are self-employed or owners of vegetable farms. They commonly used organophosphate pesticides for routine pest control activity. Currently, there is no system available to monitor pesticide usage by relevant agencies among this group of workers. Thus, there is no robust health surveillance program to assess the impact of pesticide exposure among family farmers. This study aims to determine organophosphate 
exposure, associated risk factors, and exposure risk assessment among vegetable farmers in Sabah.

\section{MATERIALS AND METHODS}

We conducted a cross-sectional study in two selected villages in Kundasang Ranau, Sabah, East Malaysia. They have located about $93.1 \mathrm{~km}$ from Kota Kinabalu City and are known as the largest vegetable producer in Sabah. The main economic activities among the villagers as a source of family income were related to vegetable cultivation. Approximately $80 \%$ of the community and 285 family farms in Kundasang were cultivating vegetables in areas covering 3020 acres, according to information from Federal Agricultural Marketing Authority (FAMA) Ranau District Office (2017). We identified 180 respondents for participation in this study after considering inclusion, exclusion criteria, and sample size determination ${ }^{8}$. The inclusion criteria were age above 18 years old and working in vegetable cultivation for at least 12 months. The exclusion criteria were farmers with mental health problems and chronic diseases before becoming involved in farming that uses pesticides. Data were collected from December 2018 to April 2019.

We took a blood sample from participants' fingertips for blood cholinesterase measurements of pesticide exposure. Steps for collecting the blood samples followed Cholinesterase Monitoring for Agricultural Pesticide Handler. Blood cholinesterase concentration was analyzed using the rapid test kit model Lovibond AF267. This method has been specified by World Health Organization Technical Sheet Report Series No. 356, item 4.4.1 since 1967 9 . The cholinesterase activity is expressed as the percentage of activity in normal blood. The reaction rate (and thus the enzyme activity of the sample) is measured by the range of color change of an indicator (bromothymol blue) present in the solution. Depending on the results obtained, the following action is recommended: $100-75 \%$ of normal (no action; retest in the near future); 74.9$50 \%$ of normal (overexposure probable; repeat test and if confirmed, suspend from further work with organic phosphorous insecticides for two weeks, then retest to assess recovery); $49-25 \%$ of normal (serious over-exposure; repeat test and if confirmed, suspend from all work with pesticides; if indisposed or ill, arrange for a medical examination); 24.9-\% of normal (severe and dangerous over-exposure; repeat test and if confirmed, suspend from all work pending a medical examination).

We developed a questionnaire based on previously published studies 10,11,12. The validated questionnaire consisted of: i) sociodemographic information: age, gender, height, weight, education; ii) working history: the period of the current job as full-time farmers, total farm size (acres), types of plants or vegetables cultivated, and income per month; iii) basic information on the use of pesticides: number of days per month working with pesticides, years of pesticide use, number of pesticide safety talks attended if any, the type of pesticide used most frequently, pesticide storage place, pesticide preparation technique, and disposal of empty pesticide containers; iv) knowledge, attitude, and practices on pesticide handling; v) medical history and selfreported symptoms of toxicity associated with pesticide use; vi) smoking. The questionnaires were administered face-to-face. Knowledge, attitude, and practices toward pesticide handling among vegetable farmers questionnaires, the maximum possible scores are 24,34 , and 26 , respectively. The minimum score to be considered good knowledge, attitude, and practice is $>75 \%$ of the correct response score ${ }^{12} \quad($ knowledge $=18$, attitude $=26$, practice $=20)^{13}$.

Hazard Identification, Risk Assessment, and Risk Control (HIRARC) were undertaken. A qualitative risk assessment using the Risk Matrix Scale was conducted to define hazards and health risks ${ }^{14}$. The HIRARC process involved: a) classifying work activities among vegetable farmers; b) identifying hazards through workers' activities done on a daily, weekly, or monthly basis and assessing what could pose significant risks to the health and safety of the workers; c) conducting a risk assessment by analyzing and estimating risks from each hazard involved by calculating or estimating the likelihood of occurrence and severity of the hazard; d) determining whether the outcome of each of the risks identified is acceptable or whether control measures need to be applied.

Data collected from the questionnaire, biological sampling, and observations were analyzed using the Statistical Package for the Social Sciences (SPSS) version 23. Data regarding the sociodemographic characteristics of the respondents were analyzed using descriptive statistics, including mean, standard deviation, frequencies, and percentages. Comparing abnormal cholinesterase and normal cholinesterase levels were performed using chisquare or Fisher exact tests for categorical data. Binary logistic regression identified the risk factors as adjusted odds ratio (AOR) and 95\% confidence interval $(\mathrm{Cl})$. The statistical significance was set at $\mathrm{p}<0.05$.

\section{RESULTS}

\section{Respondents' Characteristics}

The response rate was $91.1 \%$ (163 of 180 ). The data of the respondents was normally distributed. There were 88 male and 75 female participants with a 
mean age of 43 (SD 11.78)). Most of the respondents $(85.3 \%)$ studied until secondary school. One-third $(30.1 \%)$ of respondents were overweight (BMI 225.0). Almost half $(49.1 \%)$ of the respondents smoked. Most vegetable farmers earned an income within the range of RM1001.00 to RM3000.00 per month. (Table 1). Most vegetable farmers are smallscale farmers with holdings of less than five acres. The vegetable farmers used herbicides, insecticides, fungicides, and termites. The hazard classification of pesticides used by respondents ranged from I-b (85.5\%), II (98.2\%), III (100\%), and IV (U) $(100 \%)$. Boots, aprons, long sleeves and long pants, and head covers such as hats are the respondent's most common personal protective equipment (PPE). Field observations revealed that some vegetable farmers wear cotton clothes while working, which are unsuitable for pesticide spraying.

Table 1 Characteristics of Respondents

\begin{tabular}{|c|c|c|}
\hline Characteristic & Frequency $(\mathrm{N}=163)$ & Percentage (\%) \\
\hline \multicolumn{3}{|l|}{ Age group (years) } \\
\hline $18-30$ & 25 & 15.3 \\
\hline $31-40$ & 45 & 27.6 \\
\hline $41-50$ & 49 & 30.1 \\
\hline $51-60$ & 27 & 16.6 \\
\hline$>60$ & 17 & 10.4 \\
\hline \multicolumn{3}{|l|}{ Gender } \\
\hline Male & 88 & 54.0 \\
\hline Female & 75 & 46.0 \\
\hline \multicolumn{3}{|l|}{ Education level } \\
\hline No formal education & 3 & 1.8 \\
\hline Primary school & 8 & 4.9 \\
\hline Secondary school & 139 & 85.3 \\
\hline Diploma / Degree & 13 & 8.0 \\
\hline \multicolumn{3}{|l|}{ Body Mass Index (BMI) } \\
\hline Normal $\left(<25.0 \mathrm{~kg} / \mathrm{m}^{2}\right)$ & 114 & 69.9 \\
\hline Abnormal BMI $\left(\geq 25.0 \mathrm{~kg} / \mathrm{m}^{2}\right)$ & 49 & 30.1 \\
\hline \multicolumn{3}{|l|}{ Smoker } \\
\hline No & 83 & 50.9 \\
\hline Yes & 80 & 49.1 \\
\hline \multicolumn{3}{|l|}{ Income per month } \\
\hline$\leq$ RM1000 & 4 & 2.4 \\
\hline$\overline{\mathrm{R}} \mathrm{R} 1001$ - RM3000 & 117 & 71.8 \\
\hline RM3001 - RM5000 & 42 & 25.8 \\
\hline
\end{tabular}

Prevalence of Organophosphate Exposure Among Vegetable Farmers

According to the results of blood cholinesterase testing, $23.3 \%$ of respondents were overexposed to $\mathrm{OP}$ pesticides. The most common reported symptoms by respondents were a cough (103, $63.2 \%$ ), followed by face and eye irritation (94, $57.7 \%)$, headache $(66,40.5 \%)$, dizziness $(47,28.8 \%)$, and skin rashes $(30,18.4 \%)$.

Associated risk factors of organophosphate exposure among vegetable farmers in Sabah.

The risk factors associated with OP exposure among vegetable farmers include age, Body Mass Index (BMI), frequency (days) of pesticide exposure a month, had not attended pesticide safety training, no designated pesticide storage, and low practices scores on pesticide handling. Older farmers had higher odds of developing abnormal cholinesterase compared to younger farmers. High BMI had higher odds of developing abnormal cholinesterase compared to lower BMI. The odds of abnormal blood cholinesterase among the vegetable farmers were six times higher in farmers who were frequently exposed to OPs for five days or more in a month than one to four days. The odds of abnormal blood cholinesterase among the vegetable farmers were nine times higher in farmers who had not attended any safety training on pesticides than has had attended. The odds of abnormal blood cholinesterase among the vegetable farmers were seven times higher in farmers who did not place their pesticides in a designated area than has done it. Low practices scores on pesticide handling had higher odds of developing abnormal cholinesterase compared to high scores. (Table 2-3) 
Table 2 Associated Risk Factors of Organophosphate Exposure Among Vegetable Farmers In Sabah

\begin{tabular}{|c|c|c|c|c|c|c|c|}
\hline \multirow[t]{2}{*}{ Variables } & \multicolumn{2}{|c|}{$\begin{array}{c}\text { Abnormal } \\
\text { Cholinesterase } \\
((n=38)\end{array}$} & \multicolumn{2}{|c|}{$\begin{array}{l}\text { Normal Cholinesterase } \\
\qquad(n=125)\end{array}$} & \multirow{2}{*}{$\begin{array}{l}\text { Chi- } \\
\text { square } \\
\text { test }\end{array}$} & \multirow[t]{2}{*}{ t-test } & \multirow[t]{2}{*}{$\mathrm{p}$-value } \\
\hline & No. (\%) & $\begin{array}{c}\text { Mean } \\
(S D)\end{array}$ & No. (\%) & $\begin{array}{c}\text { Mean } \\
(\mathrm{SD})\end{array}$ & & & \\
\hline Age (years) & & $\begin{array}{l}48.0 \\
(25.7)\end{array}$ & & $\begin{array}{l}41.6 \\
(23.8)\end{array}$ & & -3.012 & 0.003 \\
\hline Body Mass Index $\left(\mathrm{kg} / \mathrm{m}^{2}\right)$ & & $\begin{array}{l}25.7 \\
(1.4)\end{array}$ & & $\begin{array}{l}23.8 \\
(2.0)\end{array}$ & & -5.234 & 0.001 \\
\hline Gender: & & & & & & & \\
\hline - $\quad$ Male & $21(23.9)$ & & $67(76.1)$ & & 0.032 & & 0.857 \\
\hline - Female & $17(22.7)$ & & $58(77.3)$ & & & & \\
\hline \multicolumn{8}{|l|}{ Education level: } \\
\hline $\begin{array}{l}\text { till primary school } \\
\text { Secondary school or above } \\
\text { Income per month (RM): }\end{array}$ & $32(21.1)$ & & $120(78.9)$ & & 0.750 & & 0.021 \\
\hline$-\quad \leq 1000$ & $0(0.0)$ & & $4(100.0)$ & & 1.998 & & 0.368 \\
\hline - $\quad \overline{1} 001-3000$ & $30(25.6)$ & & $87(74.4)$ & & & & \\
\hline$-\quad>3000$ & $8(19.0)$ & & $34(81.0)$ & & & & \\
\hline \multicolumn{8}{|l|}{$\begin{array}{l}\text { Frequency of exposure } \\
\text { (per-month): }\end{array}$} \\
\hline - Five days or more & $10(41.7)$ & & $14(58.3)$ & & 5.303 & & 0.034 \\
\hline - $\quad 1-4$ days & $28(20.1)$ & & $111(79.9)$ & & & & \\
\hline \multicolumn{8}{|l|}{ Duration of pesticide usage: } \\
\hline - $\quad$ More than ten years & $20(29.9)$ & & $47(70.1)$ & & 2.720 & & 0.132 \\
\hline - $\quad$ Less than ten years & $18(18.8)$ & & $78(81.2)$ & & & & \\
\hline \multicolumn{8}{|l|}{ Pesticide storage: } \\
\hline - $\quad$ No designated area & $32(31.7)$ & & $69(68.3)$ & & 10.406 & & 0.001 \\
\hline - $\quad$ Designated store & $6(9.7)$ & & $56(90.3)$ & & & & \\
\hline \multicolumn{8}{|l|}{$\begin{array}{l}\text { Had attended pesticide safety } \\
\text { training: }\end{array}$} \\
\hline - No & $26(45.6)$ & & $31(54.4)$ & & 24.383 & & 0.001 \\
\hline - Yes & $12(11.3)$ & & $94(88.7)$ & & & & \\
\hline \multicolumn{8}{|l|}{$\begin{array}{l}\text { Knowledge, attitude, practice } \\
\text { on pesticide handling: }\end{array}$} \\
\hline - Knowledge score & & $\begin{array}{l}22.4 \\
(1.3)\end{array}$ & & $22.8(1.1)$ & & 1.526 & 0.129 \\
\hline - $\quad$ Attitude score & & $\begin{array}{l}19.8 \\
(4.4)\end{array}$ & & $19.9(4.4)$ & & 0.076 & 0.940 \\
\hline - $\quad$ Practice score & & $\begin{array}{l}18.0 \\
(3.1)\end{array}$ & & $20.9(3.0)$ & & 5.236 & 0.001 \\
\hline
\end{tabular}

Table 3 Multivariate Logistic Regression on Factors Associated with Organophosphate Exposure Among Vegetable Farmers In Sabah

\begin{tabular}{lccc}
\hline Variable & \multicolumn{3}{c}{ Multiple Logistic Regression } \\
\cline { 2 - 4 } & $b$ & Adjusted OR (95\% Cl) & $P$ \\
\hline Age (year) & 0.07 & $1.07(1.02,1.13)$ & 0.007 \\
Body Mass Index $\left(\mathbf{k g} / \mathrm{m}^{2}\right)$ & 2.15 & $8.60(2.80,26.51)$ & $<0.001$ \\
Frequency (days) of exposure a month & 1.79 & $5.99(1.29,27.76)$ & 0.022 \\
Had no attended pesticide safety training & 2.21 & $9.08(2.97,27.74)$ & $<0.001$ \\
No designated pesticide storage & 1.93 & $6.92(1.70,28.25)$ & 0.007 \\
Low practices scores on pesticide handling & 1.79 & $6.01(1.97,18.36)$ & 0.002 \\
\hline aForward LR Multiple Logistic Regression model was applied. Multicollinearity and interaction terms were checked and not \\
found \\
Hosmer-Lemeshow test ( $p=0.323)$, classification table (overall correctly classified percentage=88.3\%), and area under the \\
ROC curve were applied to check the model fitness.
\end{tabular}


Exposure Risk Assessment of Organophosphate Pesticide among Vegetable Farmers

HIRARC is an approach to assess hazards and their related risks and to create a system to confine the risks ${ }^{14}$. The assessment results for organophosphate exposure are shown in Table 4.

Table 4 HIRARC for the Use of Organophosphate Pesticides among Vegetable Farmers

\begin{tabular}{|c|c|c|c|c|c|c|c|}
\hline \multicolumn{4}{|c|}{ Hazard Identification } & \multicolumn{3}{|c|}{ Risk Analysis } & Risk Control \\
\hline Work activity & Hazard: & $\begin{array}{l}\text { Which can cause/ } \\
\text { effect }\end{array}$ & $\begin{array}{l}\text { Existing } \\
\text { Risk } \\
\text { Control }\end{array}$ & 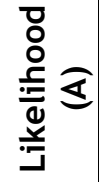 & 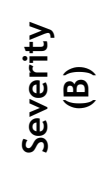 & $\begin{array}{l}\text { Risk } \\
\text { (AXB) }\end{array}$ & $\begin{array}{l}\text { Recommended } \\
\text { Control Measures }\end{array}$ \\
\hline $\begin{array}{l}\text { Purchasing } \\
\text { pesticides from } \\
\text { shop/ supplier } \\
\text { And } \\
\text { Transportation }\end{array}$ & $\begin{array}{l}\text { Chemical: } \\
\text { Direct } \\
\text { contact - } \\
\text { spillage or } \\
\text { leakage from } \\
\text { packaging. }\end{array}$ & $\begin{array}{l}\text { Skin irritation, } \\
\text { respiratory effects, } \\
\text { absorption, and } \\
\text { entry to the body } \\
\text { due to repeated } \\
\text { contact, prolonged } \\
\text { exposure potential } \\
\text { to cause cancer. }\end{array}$ & NIL & 1 & 3 & 3 & $\begin{array}{l}\text { Personal hygiene } \\
\text { PPE: Hand gloves } \\
\text { Placed pesticides at } \\
\text { the back of vehicle } \\
\text { truck. }\end{array}$ \\
\hline Storage & $\begin{array}{l}\text { Chemical: } \\
\text { Direct } \\
\text { contact - } \\
\text { spillage or } \\
\text { leakage } \\
\text { during } \\
\text { unloading or } \\
\text { loading. }\end{array}$ & $\begin{array}{l}\text { Skin irritation, } \\
\text { respiratory effects, } \\
\text { absorption, and } \\
\text { entry to the body } \\
\text { due to repeated } \\
\text { contact, prolonged } \\
\text { exposure potential } \\
\text { to cause cancer. }\end{array}$ & $\begin{array}{l}\text { Designat } \\
\text { ed store }\end{array}$ & 3 & 3 & 9 & $\begin{array}{l}\text { It required all } \\
\text { vegetable farmers to } \\
\text { provide specifically } \\
\text { designated places to } \\
\text { store pesticides. } \\
\text { Self-personal hygiene, } \\
\text { labeling of pesticide in } \\
\text { store } \\
\text { PPE: as necessarily }\end{array}$ \\
\hline $\begin{array}{l}\text { Mixing or } \\
\text { preparation of } \\
\text { pesticide } \\
\text { solutions } \\
\text { (adding water } \\
\text { and transferring } \\
\text { to the pump } \\
\text { sprayer). } \\
\text { And } \\
\text { Spraying }\end{array}$ & $\begin{array}{l}\text { Exposure to } \\
\text { OP pesticide: } \\
\text { Direct } \\
\text { contact and } \\
\text { inhalation - } \\
\text { splashing or } \\
\text { spillage of } \\
\text { pesticide. } \\
\text { Unsuitable } \\
\text { PPE or } \\
\text { without PPE }\end{array}$ & $\begin{array}{l}\text { Skin irritation, } \\
\text { difficulty breathing, } \\
\text { coughing, } \\
\text { absorption, and } \\
\text { entry to the body } \\
\text { due to repeated } \\
\text { contact, prolonged } \\
\text { exposure potential } \\
\text { to cause cancer. }\end{array}$ & $\begin{array}{l}\text { Boots, } \\
\text { long } \\
\text { sleeve } \\
\text { shirt \& } \\
\text { pants }\end{array}$ & 3 & 3 & 9 & $\begin{array}{l}\text { Personal hygiene, } \\
\text { guidance, and training } \\
\text { on emergency } \\
\text { treatment. } \\
\text { PPE: training for } \\
\text { proper use of PPE } \\
\text { (e.g., respirator and } \\
\text { nitrile rubber). } \\
\text { Substitute with } \\
\text { organic compost } \\
\text { control or use a } \\
\text { pesticide in a less } \\
\text { harmful category. }\end{array}$ \\
\hline $\begin{array}{l}\text { Cleaning and } \\
\text { minor } \\
\text { maintenance of } \\
\text { spray } \\
\text { equipment }\end{array}$ & $\begin{array}{l}\text { Chemical: } \\
\text { Direct } \\
\text { contact to } \\
\text { skin, eye, } \\
\text { oral } \\
\text { (splashing or } \\
\text { spilled) }\end{array}$ & $\begin{array}{l}\text { Skin irritation, } \\
\text { respiratory effects, } \\
\text { absorption and } \\
\text { entry to the body } \\
\text { due to repeated } \\
\text { contact, prolonged } \\
\text { exposure potential } \\
\text { to cause cancer. }\end{array}$ & $\begin{array}{l}\text { Minimal } \\
\text { PPE }\end{array}$ & 3 & 3 & 9 & $\begin{array}{l}\text { Personal hygiene } \\
\text { Health education } \\
\text { PPE: proper PPE }\end{array}$ \\
\hline
\end{tabular}




\section{DISCUSSION}

Agricultural workers who perform jobs directly in contact with pesticides are at high risk of pesticide poisoning ${ }^{15}$. Blood cholinesterase levels found that 23.3\% were overexposed to OP pesticides. This prevalence is higher as compared to the findings reported by Norsyazwani et al. (15.2\%) and Hod et al. (7\%) among farmers in Malaysia and the study conducted by Guytingco et al. (12.5\%) in Thailand among agricultural workers ${ }^{16,17,18}$. The results revealed that most of the vegetable farmers in Kundasang had experienced multiple health symptoms. The symptoms experienced by the vegetable farmers in this study are consistent with earlier studies reported in Malaysia by Haswanee et al. 2018, and Syahidatul et al., 2020. Older age is a determinant of abnormal blood cholinesterase and is similar to other studies ${ }^{19,20}$. This finding agrees with earlier studies reported in Malaysia ${ }^{21,22}$. In this study area, most agriculture practices are operated in the family as an informal business and small-scale vegetable farming. Traditionally they learn the technique from family members and nearby friends. Currently, there is no system available to monitor pesticide usage by relevant agencies among this group of workers. Since the activity was traditionally practiced long ago, older vegetable farmers were probably exposed to OP.

A health surveillance program is the time needed to monitor the impact of pesticide exposure among family farmers. This study found that one-third of the respondents were overweight with $\mathrm{BMI} \geq$ $25 \mathrm{~kg} / \mathrm{m}^{2}$. There is a significant relationship between abnormal blood cholinesterase level and BMI $\geq$ $25 \mathrm{~kg} / \mathrm{m}^{2}$. The finding is in line with results from $\bar{a}$ study conducted in Tanzania, which showed a significantly depressed blood cholinesterase level among overweight farmers ${ }^{23}$. Organophosphates are known to be lipophilic and, therefore, rapidly distribute into tissue and fat. It is essential to educate the farmers to keep their normal body weight. Many previous studies revealed the frequency of pesticides among vegetable farmers contributing to the high prevalence of pesticide poisoning. Statistical analysis of this study showed that vegetable farmers who more frequently apply pesticides have almost six times higher odds of pesticide exposure than those with less pesticide application. The increased duration of exposure to $O P$ pesticides increased the potential risk of OP pesticide exposure. This current study agrees with the surveys conducted by other researchers. It found longer exposure time and more frequency of pesticide application, increasing the risk of pesticide exposure and poisoning 25,26,27,28. The frequency can be reduced if they substitute with organic compost control or use a pesticide in a less harmful category.
Nearly two-thirds (65\%) of the respondents had attended training at least once in the last five years regarding pesticide safety provided by government authorities or pesticide suppliers. Attending pesticide safety training contributes to better knowledge, attitude, and practice among farmers ${ }^{24}$. This study found that vegetable farmers who had not participated in pesticide safety training have odds more than nine times pesticide exposure than those who have participated in pesticide safety training. The importance of training is to enhance their knowledge of pesticide use, beliefs in pesticide hazard control, and levels of safety behavior. Relevant authorities can make it compulsory to attend the training by integrating it in their agriculture or business license renewal. These interventions may facilitate knowledge enhancement and compliance with safety behaviors and become a priority for decreasing pesticide exposure among farmers.

The storage of pesticides was significantly associated with the risk of OP exposure. Nearly twothirds $(62 \%)$ of the respondents do not keep their pesticides in a designated place. Some of them keep their pesticides in the home and even in the living room area. Inadequate storage may increase the risk of exposure among vegetable farmers and their families due to highly accessible places. The association between abnormal blood cholinesterase and storage of pesticides is significant (aOR: 6.92, $95 \% \mathrm{Cl} ; 1.70-28.25, \mathrm{p}=0.007)$. The analysis concludes that vegetable farmers who have not adequately stored their pesticides have seven times greater odds of OP exposure than those keeping their pesticides in a designated store. This current study is in line with findings reported in other previous studies $^{29,30}$. The recommended storage is stock in a separate, locked cabinet or other secure structure, away from children and pets. To reduce storage problems, advisable to buy only enough pesticide for one season's use. A study on the respondents' knowledge, attitude, and practice (KAP) toward OP pesticide handling showed that all respondents had a high score on knowledge questions, with scores above $75 \%$ of the correct response. $65.7 \%$ of respondents indicate a high level of practice, and only $1.8 \%$ of respondents have a high attitude level. The odds risk analysis of OP exposure found that practices adopted by vegetable farmers toward pesticide handling were significantly associated with abnormal blood cholinesterase (aOR: 6.01, $95 \% \mathrm{Cl}$ : 1.97-18.36). These results agree with the findings of other researchers ${ }^{12,29,33}$. However, there was no significant relationship between OP exposure and knowledge levels and attitude levels of the respondents. 
This poor practice of pesticide handling can be monitored by regular educational enforcement by the relevant authority. PPE use is a last line of defense to reduce the risk of chemical hazards. Failure to use appropriate PPE during the handling of pesticides increased the risk of being poisoned by pesticides. Most of the vegetable farmers in Kundasang adopted three forms of PPE, including boots, long sleeves, long pants, and hats. This finding agrees with previous studies $23,25,29,30,31,32$. PPE availability in the local market, lack of awareness of the potential health effects of pesticides, attitudes, and practices might influence PPE use among vegetable farmers in Kundasang. A HIRARC study was undertaken to determine the magnitude of hazards, risks level, and recommended control measures. The highest risk level for vegetable farmers was a medium risk $(R R=9)$. This risk level may be elevated if vegetable farmers have no extra precautions, such as wearing PPE and hygienic practices. This finding is in line with a previous survey on safety and health in commodity agriculture in Malaysia ${ }^{15}$. The recommended control measures will be able to reduce the risk of getting $\mathrm{OP}$ exposures.

\section{CONCLUSION}

Organophosphate exposure among the vegetable farmers in Kundasang was higher than in other settings. $23.3 \%$ of them were overexposed to OP pesticides. The risk factors associated with organophosphate exposure include old age and overweight. The significant occupational factors were frequency (days) of exposure a month, had no attended pesticide safety training, did not have designated pesticide storage, and standard practices scores on pesticide handling. The exposure risk assessment level for vegetable farmers was at low-medium risk. This study provides additional evidence of the negative impacts of pesticide exposure on health. Relevant authorities such as the District Agriculture Office, Federal Agricultural Marketing Authority (FAMA), and Malaysian Agricultural Research and Development Institute (MARDI) are required to provide regular training on safe pesticide handling to increase awareness among vegetable farmers Kundasang Sabah.

\section{Limitations}

Pesticide-related health symptoms relied on selfreports by the vegetable farmers.

\section{Acknowledgments}

We would like to express our sincere gratitude to Mr. Leef Anuar Malandi, President of Kundasang Highland Vegetable Grower Association, for his support and cooperation during the field survey.
Sincere thanks go to all respondents for sharing their time and experiences with us.

Ethical Committee Approval: The Ethical Board of Universiti Malaysia Sabah (UMS) has approved this study with approval code: JKEtika 3/17(7).

Informed Consent: All study participants signed a consent form. We provided an information sheet containing the research objectives, data collection method, roles of participants, personal and community benefits, and any possible harm to the participant. Confidentiality of the information gathered was assured.

Conflict of interest: The authors declared that they have no conflict of interest.

Funding: The Universiti Malaysia Sabah (UMSGreat grant: GUG0167 2/2017) has funded this study.

\section{REFERENCES}

1. Department of Statistic Malaysia, Official Portal. Selected Agricultural Indicators, Malaysia, 2019. Released Date: 29. November 2019. Retrieved from: https: / /www.dosm.gov.my/v1/index.php?r $=$ column $/$ cthemeByCat\&cat $=72 \&$ bul_id $=\mathrm{SE}$ UxMEE3VFdBcDJhdUhPZVUxa2pKdz09\&men u_id=ZOVTZGU1UHBUT1VJMFlpaXRRR0xpdz 09

2. Mengistie, B.T., Mol, A.P.J. \& Oosterveer, P. Pesticide use practices among smallholder vegetable farmers in Ethiopian Central Rift Valley. Environ Dev Sustain. 2017;19:301-324. https://doi.org/10.1007/s10668-015-97289

3. Casey Ng. What it means to be a farming smallholder in Malaysia. Smallholder in Malaysia. UTAR Ag Science J. 2017;2:1.

4. Butler-Dawson, Jaime Lorin. Pesticide exposure, risk factors, and neurobehavioral performance among vulnerable populations. Ph.D. (Doctor of Philosophy) thesis, University of lowa, 2015. DOI: https: //doi.org/10.17077/etd.zy9vzpdh.

5. Mustapha F.A. Jallow, Dawood G.Awadh, Mohammed S.Albaho, Vimala Y.Dewi, Binson M.Thomas. Pesticide knowledge and safety practices among farmworkers in Kuwait: Results of a survey. Int J Environ Res Pub Health. 2017;14(4):340. DOI: 10.3390/ijerph14040340. 
6. Alavanja MC. Introduction: pesticides use and exposure are extensive worldwide. Rev Environ Health. 2009;24(4):303-309. doi:10.1515/reveh.2009.24.4.303

7. Rajasuriar R, Awang R, Hashim SB, Rahmat $H R$. Profile of poisoning admissions in Malaysia. Hum Exp Toxicol. 2007;26(2):7381. DOI: $10.1177 / 0960327107071857$. PMID: 17370864.

8. Krejcie RV, Morgan DW. Determining Sample Size for Research Activities. Educational and Psychological Measurement. 1970;30(3):607-610. doi:10.1177/001316447003000308

9. World Health Organization, Geneva, 1967. World Health Organization Technical Series No. 356, Safe Use Pesticide in Public Health, Sixteenth Report of the WHO Expert Committee on Insecticides.

10. The PIPAH Study, The Prospective Investigation of Pesticide Applicators' Health Study. 2017. Health and Safety Laboratory (HSL Boxton).

11. Sa'ed H. Zyoud, Ansam F. Sawalha, Waleed M. Sweileh, Rahmat Awang, Suleiman I. AlKhalil, Samah W. Al-Jabi, Nihaia B. Bsharat. Knowledge and practices of pesticide use among farmworkers in the West Bank, Palestine: safety implications. Environ Health Prev Med. 2010;15:252-261. DOI 10.1007/s12199-010-0136-3.

12. Kamsia, Shahida, Celestina, Suriani, Norlita, \& Khadizah. Knowledge, attitude, and practice of pesticide use among oil palm smallholders in Sandakan, Sabah. IOSR J Agric Vet Science. 2014;7:18-20. DOI:10.9790/2380-071121820

13. Yassin MM, Abu Mourad TA, Safi JM. Knowledge, attitude, practice, and toxicity symptoms associated with pesticide use among farmworkers in the Gaza Strip. Occ Environ Med. 2002;59:387-393.

14. Guidelines for Hazards Identification, Risk Assessment, and Risk Control (HIRARC). Department of Occupational Safety and Health (DOSH). The Ministry of Human Resources Malaysia. 2008; JKKP DP 127/789/4-47. ISBN 978-983-2014-62-1.
15. Sulaiman, Shameer Khan Bin; Ibrahim, Yusoff; Jeffree, Mohammad Saffree. Evaluating the perception of farmers towards pesticides and the health effect of pesticides: A cross-sectional study in the oil palm plantations of Papar, Malaysia. Interdisciplinary toxicology, 2019; 12(1): 15.

16. Norsyazwani Mohammad, Emilia Zainal Abidin, Nor 'Aqilah Amani Zainal Mubarik, Vivien How, Sarva Mangala Praveena, Zailina Hashim. Blood cholinesterase level and its association with neurobehavioral performance due to insecticide exposure among male cocoa farmers in Pahang and Perak, Malaysia. Asian J Agri Biol. 2018; Special Issue:29-41.

17. Rozita Hod, Azimatun Noor Aizuddin, Shamsul Azhar Shah, Mohd Rohaizat Hassan, Nazarudin Safian and Mohd Hasni Jaafar. Chlorpyrifos blood level and exposure symptoms among paddy farmers in Sabak Bernam, Malaysia. Int J Pub Health Res. 2011;1(1):1-6.

18. Andrea Guytingco, Phayong Thepaksorn \& Richard L. Neitzel. Prevalence of abnormal serum cholinesterase and associated symptoms from pesticide exposure among agricultural workers in the south of Thailand. J Agromed. 2018;23(3):270-278, DOI: 10.1080/1059924X.2018.1470049

19. Syahidatul, Nur Jambari, Aqilah Izzah, Nurul Samad, Abdul Anua, Siti Marwanis Ruslan, Rumaizah. Knowledge, attitude, and practice (KAP) on pesticide exposure among farmers knowledge, attitude and practice (KAP) on pesticide exposure among farmers in Kota Bharu, Kelantan. Malay $J$ Med Health Sciences. 2020;2636-9346.

20. Ayuk B.Tambe, Baleba M.R. Mbanga, Dapi L. Nzefa, Media G Nama. Pesticide usage and occupational hazards among farmers working in small-scale tomato farms in Cameroon. J Egypt Pub Health Assoc. 2019;94:20. https://doi.org/10.1186/s42506-019-0021$\mathrm{x}$.

21. H. Vivien, Z. Hashim, P. Ismail, et al., Biological monitoring of genotoxicity to organophosphate pesticide exposure among rice farmers: exposure-effect continuum study. J Occ Health Epid. 2013;2(1):27- 36. 
22. Miswon, Nurul \& Hashim, Zailina \& How, Vivien \& Chokeli, Raihanah. Blood cholinesterase level and learning ability of primary school children in an agricultural village, Tanjung Karang, Malaysia. J Advances Med Medical Res. 2015;8(1):5260.

https://doi.org/10.9734/BJMMR/2015/168

04.

23. Kapeleka, Jones A, Sauli, Elingarami, Sadik, Omowunmi, Ndakidemi, Patrick A.,. Biomonitoring of acetylcholinesterase (AChE) activity among smallholder horticultural farmers occupationally exposed to mixtures of pesticides in Tanzania. J Environ Pub Health 2019 DOI: $10.1155 / 2019 / 3084501$

24. Damalas CA, Koutroubas SD. Farmers' exposure to pesticides: toxicity types and ways of prevention. Toxics. 2016;4(1):1. https://doi.org/10.3390/toxics4010001

25. Johnstone, Kelly Rose. Organophosphate exposure in Australian agricultural workers: human exposure and risk assessment (2006). Ph.D. thesis, Queensland University of Technology.

26. Kim Ji-hyun, Kim Jaeyoung, Cha Eun Shil, Ko, Yousun, Kim Doo Hwan. Work-related risk factors by severity for acute pesticide poisoning among male farmers in South Korea. Int $J$ Environ Res Pub Health. 2013;10:1100-1112.

27. Anamai Thetkathuek, Pornthip Yenjai, Wanlop Jaidee, Patchana Jaidee \& Poonsak Sriprapat. Pesticide exposure and cholinesterase levels in migrant farmworkers in Thailand. J Agromed. 2017;22(2):118-130.

DOI:
28. Muhammad Izzat Othman, Zailina Hashim. Exposure to organophosphate pesticides and neurobehavioral performance among paddy farmers in Tanjung Karang, Selangor. Asia Pacific Environ Occ Health J. 2018;4:235 - 42.

29. Lekei, E.E., Ngowi, A.V. \& London, L. Farmers' knowledge, practices and injuries associated with pesticide exposure in rural farming villages in Tanzania. BMC Pub Health. $\quad 2014 ; 14: 389$. https://doi.org/10.1186/1471-2458-14-389

30. Manyilizu WB, Mdegela RH, Helleve A, Skjerve $E$, Kazwala $R$, Nonga $H$, Muller $M$, Elisabeth L, Lyche LJ, et al. Self-reported symptoms and pesticide use among farmworkers in Arusha, Northern Tanzania: a cross-sectional study. 2017 MPDI. DOI: $10.3390 /$ toxics 5040024

31. Zhang, X., Zhao, W., Jing, R. et al. Workrelated pesticide poisoning among farmers in two villages of Southern China: a crosssectional survey. BMC Pub Health. 2011;11:429.

https: / / doi.org/10.1186/1471-2458-11-429

32. Jacqueline Cotton, John Edwards, Muhammad Aziz Rahman, Susan Brumby, 2018. Cholinesterase research outreach project (CROP): point of care cholinesterase measurement in an Australian agricultural community. Environ Health. 2018; $17: 31$ https: //doi.org/10.1186/s12940-018-03741.

33. Dinesh Neupane, Erik Jors, Lars Brandt, 2014. Pesticide use, erythrocyte acetylcholinesterase level and selfreported acute intoxication symptoms among vegetable farmers in Nepal: a crosssectional study. Environ Health. 2014;13:98 DOI: 10.1186/1 